American Journal of Pharmaceutical Education 2020; 84 (10) Article 8039.

\title{
REVIEW
}

\section{A Scoping Review of Pharmacy Preceptor Training Programs}

\author{
Gillian J. Knott, MPharm, BPharm, Martina F. Mylrea, PhD, MEd, Beverley D. Glass, PhD, BSc (Hons) \\ James Cook University, Townsville, Queensland, Australia \\ Submitted February 23, 2020; accepted May 29, 2020; published October 2020.
}

Objective. To review the literature pertaining to pharmacy preceptor training programs.

Findings. Preceptor training is becoming increasingly important to maintain the quality of experiential training and professional development of pharmacy students, preregistration trainees, and residents. This review found limited documented examples of preceptor training programs and wide variation in both their design and delivery, which was attributed to the diversity of pharmacy practice workplaces and the different types of trainees. The majority of programs included a significant online component, often supported by a face-to-face orientation, with a focus on developing core competencies and with some tailoring of content to suit the specific workplace environment. Evaluations of these training programs showed high preceptor satisfaction rates, with preceptors appreciating the ease of access of online training and the benefits of interaction with other preceptors in face-to-face training. Preceptors also reported positive changes in their behavior during and attitudes toward precepting and an increased understanding of student learning.

Summary. This review has highlighted that a structured and evidence-based approach to preceptor training is needed. Programs should be educationally sound, practically focused, and flexible in meeting the needs of a diverse range of preceptors and practice environments. Prospectively, programs should be evaluated not only in terms of outcomes for preceptors, but also for student, preregistration trainee, and resident engagement and attainment of educational outcomes.

Keywords: preceptor development, tutor, training, feedback and assessment

\section{INTRODUCTION}

Over the past 30 years, the role of the pharmacist has evolved and expanded, with the emphasis moving from a medication supply function towards the provision of comprehensive pharmaceutical care. ${ }^{1,2}$ As a result of the changing pharmacy landscape and an increased requirement for high quality practice-ready pharmacy graduates, experiential training within the academic curriculum and prior to licensure has become increasingly important. The movement to the Doctor of Pharmacy (PharmD) degree as the sole entry-level degree in the United States after July 2000 renewed the focus on experiential education, with updated guidelines for advanced pharmacy practice experiences (APPEs) that required preceptors to deliver an estimated $30 \%$ of the PharmD curriculum. ${ }^{3,4}$ Similarly, pharmacy faculties in Canada are transitioning to a PharmD educational model, with the requirement for experiential education increasing significantly. ${ }^{5}$ The training and development of pharmacy residents has also evolved in response to an increase in the number and

Corresponding Author: Gillian J. Knott, James Cook

University, Townsville, Queensland, Australia. Tel: +61 (0)

747816180. Email: gillian.knott@jcu.edu.au variety of pharmacy practice settings and specialties. This requirement for increased student experiential training and resident development has created a major role for pharmacy preceptors, making their training and support a priority. ${ }^{1,5,6}$

A preceptor may be defined as a practicing pharmacist who serves as a role model to guide a pharmacy student, preregistration trainee, or resident in the development of their professional knowledge, attitudes, and practice skills. ${ }^{7-10}$ The quality of student experiential training and resident development has been reported to be highly dependent on the preceptor. ${ }^{1,9,11-13}$ However, while these preceptors provide a vital link between theory and practice, they are largely not remunerated for their service, yet universities as well as residency programs are becoming increasingly reliant on their willingness to voluntarily contribute their time and expertise to training the next generation of pharmacists. ${ }^{7,14}$ In order to continue to provide high-quality experiential training and maintain the preceptor-student relationship, universities have an obligation to provide adequate and appropriate training to support their preceptors. ${ }^{12,14}$ Ongoing preceptor development is also critical to a successful residency training experience for PharmD graduates and leads to a more highly skilled and satisfied workforce. ${ }^{13}$ 


\section{American Journal of Pharmaceutical Education 2020; 84 (10) Article 8039.}

The Accreditation Council for Pharmacy Education (ACPE) Standards 2016 specify that pharmacy preceptors must be orientated to the mission of their particular program and must be provided with professional development in line with their educational responsibilities. ${ }^{15}$ Similarly, the Canadian Council for Accreditation of Pharmacy Programs (CCAPP) requires pharmacy faculties to have established criteria and training for preceptors and commitment from preceptors to support the teaching process. The American Society of HealthSystem Pharmacists (ASHP) outlines standards for pharmacy residency programs, which include standards for preceptors in terms of qualifications, teaching roles, and resident assessment. In the United Kingdom, pharmacy training has become more clinically focused, with all students now completing a Master of Pharmacy (MPharm) degree prior to entering their intern year. Despite these changes to the UK curriculum, the General Pharmaceutical Council has no specified requirements for experiential clinical training within the degree or for the training of student or intern preceptors (termed tutors in the United Kingdom). ${ }^{16}$ In Australia, it is recommended but not compulsory for preceptors of intern pharmacists to undertake a preceptor training program in preparation for their precepting role. ${ }^{17}$ The Australian Pharmacy Council (APC), requires that all professionals who assess students or interns are suitably qualified, experienced, prepared for their role, and provided with appropriate guidance and support. ${ }^{18}$

The expansion of the role of pharmacists worldwide has resulted in an increased number and diversity of student experiential and residency training programs, thus highlighting the important role of the preceptor and the need for quality preceptor training. ${ }^{1,2,19}$ Considering current preceptor training requirements, the aim of this review was to examine the available literature regarding pharmacy preceptor training programs.

\section{METHODS}

This scoping review was conducted using the six stage methodology of the Johanna Briggs Institute, ${ }^{20}$ which was based on the original scoping review framework of Arksey and O'Malley, with subsequent enhancement by Levac and Colquin. ${ }^{21,22}$ A scoping review is particularly suitable for this topic which encompasses a broad and diverse range of literature, enabling a comprehensive overview to be provided, from which gaps and areas of interest can be more easily identified. The research question to be addressed by this review is: "How are pharmacy preceptor training programs currently being designed, delivered, and evaluated?"
An initial database search was conducted using five relevant databases: Cinahl, Medline (Ovid), Scopus, ERIC (educational), and Informit A+ education. Keywords included pharmacist or pharmacy, preceptor, tutor, trainer or preceptorship, training or development, and program evaluation. The inclusion criteria for the initial search included all literature, full texts, and abstracts in English. A further search using keywords identified in the initial articles was carried out, and the reference lists and citations for all articles were also searched for additional literature.

The article selection process was conducted in accordance with the Preferred Reporting Items for Systematic Reviews and Meta-Analyses (PRISMA) system and is outlined in detail in Figure 1. Following the identification of relevant articles, each article was screened by title and abstract and, after the removal of duplicates, the researchers decided to refine the search criteria by setting a timeframe of the past 20 years (ie, literature published between 1998 and the present) and excluding all literature relating to the training of students rather than preceptors. The 20-year time frame was chosen because of the significant changes in experiential education that occurred around the year 2000 .

A review team of three researchers were involved in independently assessing the remainder of these articles against the inclusion and exclusion criteria. Articles included could be from any country and were related to the training of preceptors of pharmacy students, interns, and/ or residents. Articles that were excluded were those that focused on: interprofessional education; training of students, interns, or residents; preceptor roles (including mentoring), careers or needs analyses; specific content of preceptor training programs and standards, guidelines, or frameworks. Following collaborative discussion, the research team reached a consensus regarding the final articles to include in the review. A summary of the selected articles is presented in Appendix 1. This summary includes for each article the authors, year, country of origin, study design, participants, setting, and outcomes (for studies). The study outcomes were mapped to three main domains: domain 1 was program design, domain 2 was program delivery, and domain 3 was program evaluation.

With the majority of articles included in this review being cohort studies, the researchers decided that the Newcastle-Ottawa Scale was an appropriate tool to evaluate study quality, as this scale was designed to assess the quality of non-randomized case-control or cohort studies in meta-analyses. Using this scale, quality assessment was scored using a star system, with a maximum of four stars awarded for each article. The three criteria considered in this assessment are the study group 


\section{American Journal of Pharmaceutical Education 2020; 84 (10) Article 8039.}

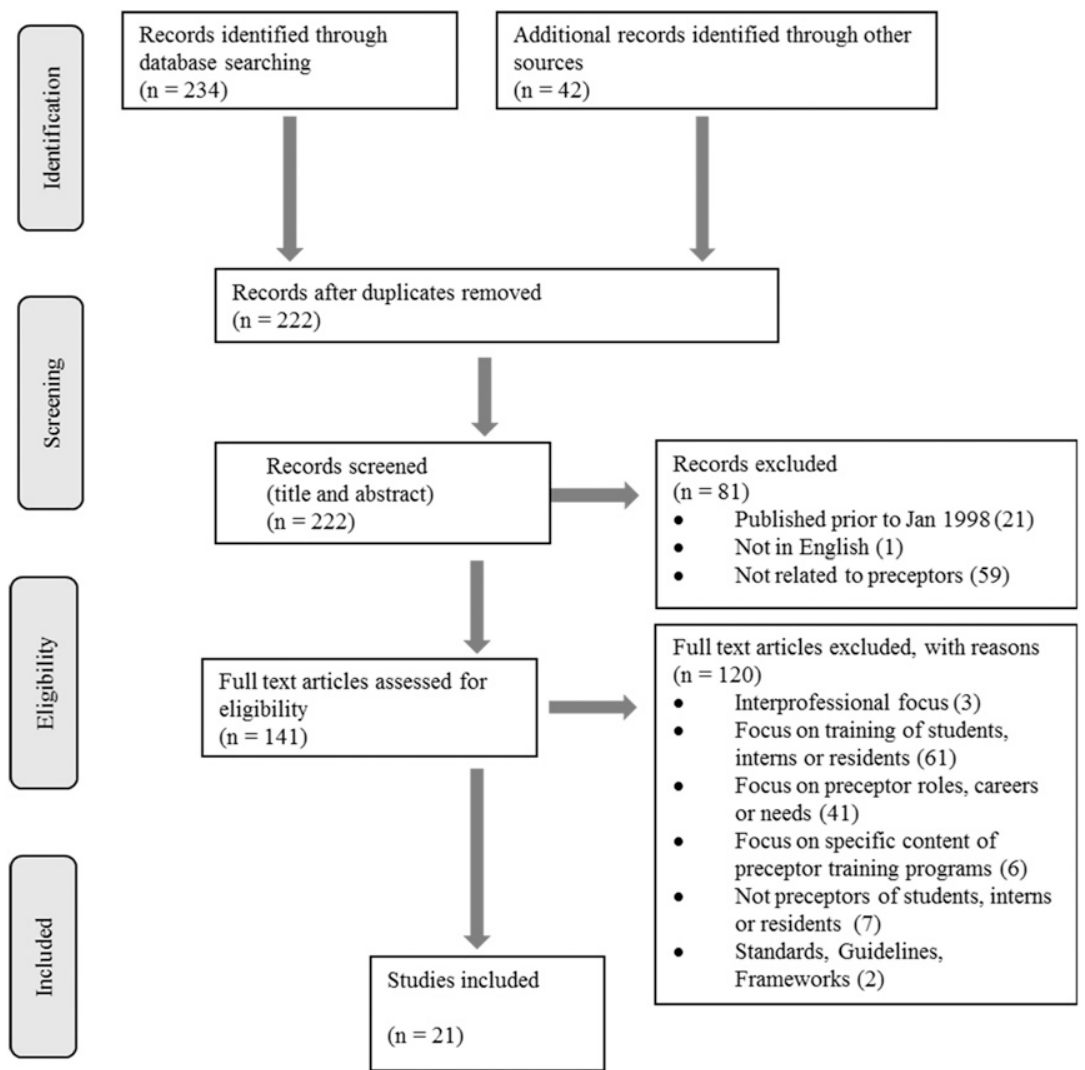

Figure 1. PRISMA (Preferred Reporting Items for Systematic Reviews and Meta-Analyses) Flow Diagram of Scoping Review Search Strategy

selection, comparability of study groups, and assessment of the outcome of interest. ${ }^{23}$

\section{RESULTS}

The search strategy identified 276 articles, and following the removal of duplicates, 222 articles remained. After refinement of the search and the application of inclusion and exclusion criteria, 21 articles were considered appropriate for inclusion in the review (Appendix 1). The 21 articles included were from four different countries, with the majority (14 articles) being from the United States, followed by Canada (three articles), Australia (three articles), and the United Kingdom (one article). Years of publication ranged from 2004 to 2018, with over $75 \%$ of the articles being published in the latter half of this period. Eight of the 21 articles described studies relating to pharmacy preceptor training programs in general, ${ }^{1,3,8,24-28}$ while 10 focused specifically on hospital pharmacy ${ }^{10,13,29-36}$ and two on community pharmacy. ${ }^{37,38}$ Of the 10 hospital-focused articles, eight discussed residency preceptors, with one article covering both student and residency preceptors ${ }^{35}$ and one looking at student preceptors only. ${ }^{32}$ Three of the hospital-based articles (two from the Unites States and one from Canada) were surveys of hospital residency coordinators that investigates current preceptor training and development practices in hospital residency programs. ${ }^{29-31}$ A thesis investigating preceptor recruitment, training, and retention strategies across the United States was also included. ${ }^{39}$ The majority (62\%) of the studies involved less than 60 participants; however, the number of participants in each study ranged from 14 hospital-based residency coordinators in Canada $^{29}$ to 382 pharmacy preceptors across five US universities. ${ }^{26}$ All three of the articles from Australia outlined various aspects of the same preceptor training program, including the design, ${ }^{8}$ delivery, ${ }^{24}$ and evaluation of this program. ${ }^{24,27}$

Across the 21 articles in this review, 15 different preceptor training programs are described, 3,4,10,13,24-26,28,32-38 with eight of the articles including a formal evaluation of the program. ${ }^{3,10,25,26,28,32,37,38}$ The majority of evaluations used preceptor or student surveys, but a few were conducted via post-training preceptor focus groups or interviews. Of the eight formal evaluations of preceptor training programs, only three described both a preceptor and a student evaluation, ${ }^{3,37,38}$ with the remaining articles only conducting a preceptor evaluation. Additionally, three articles conducted both pre- and post-training evaluations. ${ }^{3,25,38}$ Only two of the 


\section{American Journal of Pharmaceutical Education 2020; 84 (10) Article 8039.}

eight program evaluations were of hospital preceptor training programs, with both of these relating to undergraduate preceptor training programs ${ }^{10,32} \mathrm{~A}$ brief description of the outcomes of each study is outlined in Appendices 1 and 2, with Appendix 1 including articles on preceptors of undergraduate students and Appendix 2, articles on preceptors of postgraduate students (pre-registration trainees and residents). Preceptor training methods included both face-to-face sessions and web-based modules, often in conjunction with written materials such as a preceptor manual, pre-session assignments, and self-study readings. Support measures included online preceptor networks, preceptor meetings, preceptor "pearls," and regular newsletters (Appendices 1 and 2). Preceptor training program evaluations were predominantly very positive, with high preceptor satisfaction rates. Preceptor comments from the surveys and interviews described many program benefits, including ease of access to training, self-directed learning, interactive, good to share ideas, positive changes to behaviour and attitudes, good insight into student learning, and changes to their approach to being a preceptor. ${ }^{3,10,24-28,32,37,38}$ The three documented student evaluations of preceptors also provided very positive results overall. ${ }^{1,37,38}$

When assessing the quality of the articles using the Newcastle-Ottawa scale, the majority satisfied the first criterion of selection, being a somewhat or truly representative sample of the cohort being studied. The second criterion of comparability scored poorly, with only four of the 21 studies being designed to include a control cohort; the four were in the form of either a pre- or postintervention survey of pharmacy preceptors or a pre- and post-intervention student evaluation of preceptors. Approximately half of the articles met the final criterion in that they provided an independent, blind assessment of outcomes or had allowed an appropriate length of time from the study to follow up, or both. A summary of the results of this quality assessment is provided in Figure 2.

\section{DISCUSSION}

The move to the PharmD curriculum model in the United States in 2000 has been the stimulus for much research and development surrounding the training of and support provided to preceptors. With Canadian faculties in the final stages of also transitioning to the PharmD degree, not surprisingly, much of the literature on this topic has originated from these two countries. The increasing need for preceptor training and support has been well documented; $, 13,5,6,9,11,39,40$ however, there is still much debate about the optimal approach to this training in terms of design, development, and evaluation of training programs.

The training and support needs of pharmacy preceptors have been considered and addressed by professional bodies in many countries, with a range of recommendations and guidelines developed in recent years. The 2011-2012 AACP Professional Affairs Standing Committee recommended the development of a nationally recognized preceptor training program culminating in recognition as a Master Preceptor. ${ }^{6}$ The committee suggested that all colleges of pharmacy should institute and continuously review a development program for their preceptors, which ensures that they are competent and supported with appropriate resources and that they receive recognition for their work. These programs should be delivered using a variety of approaches (eg, face to face, online, web-based, and paper-based) to accommodate preceptor needs. The 2017-2018 Report ${ }^{41}$ of the Professional Affairs Standing Committee also recommended that, in order to foster the ongoing professional development of preceptors, training programs should make use of continuing professional development strategies, such as the newly developed online preceptor self-reflection/self-assessment tool for entrustable professional activities (EPAs). This would allow preceptors to self-assess their competency to teach and assess EPAs for new pharmacy graduates. The continuing professional

\begin{tabular}{l|l|l|l} 
& \multicolumn{3}{|c}{ Assessment Criteria } \\
\hline & $\begin{array}{l}\text { Selection } \\
\text { Max 1 star }\end{array}$ & $\begin{array}{l}\text { Comparability } \\
\text { Max 2 stars }\end{array}$ & $\begin{array}{l}\text { Assessment of outcome } \\
\text { of interest } \\
\text { Max 1 star }\end{array}$ \\
\hline Number of articles & 19 & 10 \\
\hline Overall Quality Assessment Score & $\begin{array}{l}4(1 \text { star }) \\
0(2 \text { stars })\end{array}$ \\
\hline Number of stars & \multicolumn{2}{|}{} \\
\hline$\star \star \star \star$ & Number of articles \\
\hline$\star \star \star$ & 0 \\
\hline$\star \star$ & 4 \\
\hline$\star$ & 6 \\
\hline No stars & 9 \\
\hline
\end{tabular}

Figure 2. Newcastle-Ottawa Assessment Scale Scores for Included Articles ${ }^{23}$ 


\section{American Journal of Pharmaceutical Education 2020; 84 (10) Article 8039.}

development approach to ongoing training was also used by Tofade and colleagues who trialed an online continuing professional development training portfolio to promote reflective, self-directed learning in preceptors, to improve teaching, and to set realistic learning goals for students. $^{28}$

The Canadian Experiential Education Project in 2018 resulted in the design and development of a prototype for a national preceptor development program in Canada that could be used to improve preceptor competency through a web-based learning platform. ${ }^{5,42,43}$ They proposed that preceptor training programs should be based on a set of core competencies and performance indicators, include preceptor engagement and retention strategies, and provide preceptors with both initial orientation and ongoing development. Results from Johansen's nationwide survey of US experiential education academics also supported the requirement for preceptors to complete an orientation program as well as regular ongoing development programs. ${ }^{39}$

As outlined in Appendices 1 and 2, a diverse range of design and delivery approaches to pharmacist preceptor training has been described in this scoping review. This range is not surprising given the variety and complexity of pharmacy practice environments both within and across countries, which have inevitably led to different preceptor learning needs. ${ }^{3}$ Because of this diversity, Young and colleagues have suggested that training programs will need to be tailored to suit the individual requirements of both the preceptor and the student. ${ }^{9}$ However, a recent Australian study by Lucas and colleagues that investigated the role of preceptors concluded that even in light of the diversity of experiential placement settings, some standardization of preceptor training was important, particularly in the area of assessment and feedback. ${ }^{19}$ Researchers from the United States concluded that, while there are core generic skills which should be covered in all preceptor training programs, a comprehensive program should also include a range of additional educational content with a high degree of flexibility to accommodate individual preceptor needs. ${ }^{3}$ The research undertaken in both the United Kingdom and Australia, although limited, has highlighted the importance of a consistent approach to preceptor training given the current lack of consistency reported in the training experience of UK pre-registration pharmacists posing potential risks to quality and patient safety. ${ }^{2,25}$ A pilot preceptor training program was developed in the United Kingdom and evaluated by Davison and colleagues to begin to address this problem. ${ }^{25}$ In Australia, the national training program that was developed jointly by four Australian universities provided a core education and support program consisting of five online educational modules that could be customized and used by other undergraduate programs or expanded for graduate programs. ${ }^{8,24,27}$

Of the 15 individual preceptor programs included in this review, seven were specific to hospital pharmacies, with five of the seven describing residency preceptor programs. While both researchers and researchers may assume that the principles of effective precepting are the same for both undergraduate and postgraduate preceptors, there may be some differences in the level of preceptor training needed for these two groups of students. A more structured environment may exist in residency programs where a residency program director has overall responsibility for preceptor development and evaluation. The importance of succession planning in hospital residency programs has also been recognized, with some facilities providing programs for "preceptors in training" and for residents to precept students. ${ }^{13,31,35}$ Resident preceptors are required to comply with the accreditation guidelines of the American Society of Health-System Pharmacists (ASHP), which include the preceptor roles of instructing, modeling, coaching, and facilitating. ${ }^{13}$ They are expected to have advanced clinical knowledge in their area of practice, excellent teaching ability, the ability to assess resident performance and provide feedback, and professionalism. However, while the requirements and expectations of the hospital residency preceptor are clearly indicated in the guidelines, there is little detail as to exactly how these preceptors should be trained so that they achieve these standards. ${ }^{13,30,31}$ Some studies indicate that most hospitals have some form of residency preceptor development program, but they are diverse in structure and frequently lacking in standardization of preceptor competencies or certification. ${ }^{29-31}$ The hospital-based preceptor training programs described in this review ranged from fully online to fully face-to-face training, with most including an orientation program along with ongoing development in the form of foundational workshops, continuing education sessions, face-to-face educational sessions, preceptor pearls, and self-study. ${ }^{13,29,34}$ Only two preceptor training programs specifically in community-pharmacy were identified in the literature, with Cerulli and Briceland in 2004 describing many obstacles to the provision of pharmaceutical care in the busy community pharmacy environment, such as time and workflow issues, which created difficulties when designing and delivering appropriate preceptor training. ${ }^{34}$ Macedo and colleagues discussed a community pharmacy trial of a specific teaching exercise in providing student feedback as a method of preceptor development. While the trial was determined to be an effective training method, it was also time consuming and resource intensive. ${ }^{38}$ 


\section{American Journal of Pharmaceutical Education 2020; 84 (10) Article 8039.}

Overall, the most common preceptor training approaches identified by this review were face-to-face sessions (12 programs) and online modules (9 programs), with six of the 15 programs outlined including a combination of these two methods. An online option for training is considered to be convenient and often a necessity because of the widespread geographical distribution of preceptors. Various online preceptor development resources such as the Therapeutic Research Center's Pharmacist's Letter ${ }^{44}$ have recently been developed in the United States and have been used by some pharmacy programs for their preceptors. ${ }^{13,34,43}$ However, technology is not considered to be a complete substitute for face-to-face training, with Assemi and colleagues reporting that $70 \%$ of preceptors preferred locally run face-to-face development courses. ${ }^{45}$ Face-to-face interactions were thought to be important in the creation of deep meaningful relationships between preceptors and consequently to promote preceptor networking. ${ }^{40}$ The importance of flexibility in a training program was also emphasized, with several studies identifying time constraints and problems with preceptor availability to be significant barriers to training. . $^{30,32,36}$

In addition to training, various strategies for support, recognition, and integration of preceptors have been used. Preceptor support is commonly provided in the form of online support networks, preceptor newsletters, preceptor training manuals, and mentoring of inexperienced preceptors. Given the key role that preceptors play in pharmacy education in the linking of theory to practice, the importance of ongoing communication has been highlighted, with a focus on preceptor recognition and integration into the academic team. Strategies to maintain or improve communication have included regular placement site visits, networking with professional organizations, preceptor advisory and discussion boards, and preceptor excellence awards. ${ }^{3,4,8,13,32,36,43}$ In consideration of the significant teaching contribution of preceptors to the undergraduate curriculum, many colleges are formalizing the link with preceptors by offering adjunct teaching appointments or developing academies of preceptors. ${ }^{4,39}$ This practice reinforces the responsibilities of colleges and schools of pharmacy in the provision of preceptor development. Many pharmacy programs have also recognized that because of the time spent with students and interns and the predominantly voluntary nature of precepting, some form of incentive might be needed to attract preceptors to undertake training and development programs. The provision of CPD credits for precepting and preceptor development activities, which count towards pharmacists' licensure renewal, has been recommended $^{37,39,46}$ and this practice has been incorporated into a number of training programs. . $^{3,4,10,26,28,37}$
A range of issues and concerns have been raised by preceptors from all of the various settings, including the problems of lack of time and remuneration, appropriate preceptor acknowledgment, and ways of dealing with unmotivated or problem students. ${ }^{12,45}$ Particular areas for training identified by the literature include teaching skills, how to serve as a role model, making time for students, effective communication with students, and student assessment and feedback. ${ }^{9,12,45}$ With regard to assessment and feedback, many preceptors felt that they either did not have adequate time or were not appropriately qualified to evaluate students or residents. ${ }^{1,12,14,19,30,47}$ Feedback is a crucial element of the preceptor role, and it has been reported that providing effective written and verbal feedback is one of the greatest challenges for preceptors. ${ }^{30,38,48}$ On a positive note, many benefits of training for preceptors have been documented, including an increase in preceptor confidence and career satisfaction, a better ability to maintain clinical skills, and increased job opportunities. $^{45,49}$

Notably, a formal program evaluation was performed for only eight of the 14 programs included in this review, with the majority of the eight evaluations being qualitative in nature and based on feedback from the preceptors. All three program evaluations in which student feedback was obtained involved undergraduate preceptors. ${ }^{3,37,38}$ Vos and Trewet, in their pre and postintervention evaluation of a preceptor program, found that while students rated preceptors higher after the program, no increase occurred in the number of preceptors rated by students as excellent, with improvement in scores occurring mainly for the lower-rated preceptors. ${ }^{3}$ The remaining two program evaluations involving students were conducted post-training only, with preceptors receiving predominantly positive feedback from students. ${ }^{37,38}$

In evaluating a training program, it is useful to consider Kirkpatrick's well-known model of educational effectiveness. The model looks at the four criteria of reaction, learning, behavior, and results, with reaction and learning focusing on the impact of the training program itself and behaviour and results focusing on the changes which occur as a result of training. The majority of evaluations included in this review have focused on the effect of the training program on participants (ie, the reaction and learning levels of the Kirkpatrick model). Little evidence currently supports a relationship between the reaction and learning and behaviour and results. Thus, while the results of the program evaluations included in this review were overall very positive, it would be optimal to also consider the effect on work performance, student engagement, and student outcomes when evaluating programs. ${ }^{50}$ Accurate measurement of student outcomes 


\section{American Journal of Pharmaceutical Education 2020; 84 (10) Article 8039.}

may be difficult to achieve, particularly given that pre and post-intervention data would be required. In the case of a student experiential placement or residency, there are likely to be changes in both student knowledge and attitude over time, which may affect their pre- and post-intervention responses to preceptor evaluations. ${ }^{3}$

Based on the studies identified in this review, preceptor programs would benefit from the inclusion of training in core skills such as teaching and mentoring, with the addition of site-specific material as necessary. This is supported by the fact that most requirements for training of preceptors involved generic skills, eg, providing feedback, not related to a specific practice setting or type of trainee. ${ }^{5,30,36,42}$ This also reflects the need for collaboration between colleges of pharmacy and residency programs to share resources and provide a standard framework, with further tailoring made by the institution to suit their program. ${ }^{3,8,19,26,36}$ Initial orientation as well as an ongoing development program are essential to promote continued excellence in precepting and improve preceptor retention. ${ }^{5,13,39}$ Programs should be flexible in their delivery and take into account the time constraints preceptors have and that preceptors are often not remunerated for their work. This is consistent with the preference of most schools for targeted and interactive online programs, which also address the geographical issues associated with training preceptors in scattered locations. ${ }^{1,5}$ The provision of opportunities for face-to-face interaction supplementary to online training was found to be desirable but not essential. ${ }^{3,45}$ Strategies should also be put in place to engage, support, and retain preceptors as this will ultimately impact their performance and adoption of positive learning practices. ${ }^{7,13,39}$

While this review highlighted the paucity of available literature on pharmacy preceptor training programs, it also revealed the overall poor quality of this literature as the authors determined using the Newcastle-Ottawa quality assessment scale. This may be in part because of the preliminary nature of current research into preceptor training. The authors expect that the quality of the literature will improve as this emerging area of research continues to develop. Further investigation into the needs of the preceptor in specific environments and student perceptions of the role of the preceptor may yield information that would be useful in program design. The lack of quality assurance in current preceptor training programs also needs to be addressed, particularly focusing on ways to effectively measure outcomes such as student engagement and learning.

\section{CONCLUSION}

While the increasing need for pharmacy preceptor training has been highlighted in recent years, this review shows that there are a limited number of peer-reviewed reports related to preceptor training and support programs. Of the preceptor training programs that have been documented, there is significant variation in their design and delivery methods (Appendices 1 and 2). Furthermore, there are even fewer examples of post-training evaluations, which are considered essential for quality assurance. ${ }^{24}$ $26,32,37,38$ While the diversity of current preceptor training programs has been recognized as positive to allow flexibility and reduced barriers to preceptor development, a more structured and evidence-based approach to training may be necessary to maintain educational quality, particularly in the area of student evaluation and feedback. Quality assurance should be an essential part of these programs, with evaluations aiming to address not only the preceptor perspective but also confirm a positive link between preceptor training and student performance and outcomes.

\section{REFERENCES}

1. Buck B, Wilkinson S, Phillips H. The complexity and importance of residency precepting: a series introduction. Hosp Pharm.

2012;47(8):603-607.

2. Jee $\mathrm{S}$, Schafheutle E, Noyce P. Is pharmacist pre-registration training equitable and robust? Higher Education, Skills and Workbased Learning. 2019;9(3):347. https://doi.org/10.1108/HESWBL07-2018-0071

3. Vos S, Trewet C. A comprehensive approach to preceptor development. Am J Pharm Educ. 2012;76(3):Article 47.

4. Boyle C, Morgan J, Layson-Wolf C, Rodriguez de Bittner M. Developing and implementing an academy of preceptors. Am J Pharm Educ. 2009;73(2):Article 34.

5. Mulherin K, Walter S, Cox C. National preceptor development program (PDP): Influential evidence and theory. The first of a 3-part series. Curr Pharm Teach Learn. 2018;10(3):255-266.

6. Harris B, Butler M, Cardello E, et al. Report of the 2011-2012 AACP Professional Affairs Committee: addressing the teaching excellence of volunteer pharmacy preceptors. Am J Pharm Educ. 2012;76(6):Article S4.

7. Fejzic J, Henderson A, Smith N, Mey A. Community pharmacy experiential placement: comparison of preceptor and student perspectives in an Australian postgraduate pharmacy programme. Pharm Educ. 2013;13(1):15-24.

8. Marriott J, Taylor S, Simpson M, et al. Australian national strategy for pharmacy preceptor education and support. Aust J Rural Health. 2005;13(2):83-90.

9. Young S, Vos S, Cantrell M, Shaw R. Factors associated with students' perception of preceptor excellence. Am J Pharm Educ. 2014;78(3):53.

10. Woloschuk D, Raymond C. Development and evaluation of a workplace-based preceptor training course for pharmacy practitioners. Can Pharm J. 2012;145(5):231-236.

11. Cox C. Sharing ideas in experiential education. Am J Pharm Educ. 2012;76(3):45.

12. Chaar B, Brien J, Hanrahan J, McLachlan A, Penm J, Pont L. Experimental education in Australian pharmacy: preceptors' perspectives. Pharm Educ. 2011;11(1):166-171.

13. Elmore L, Blair M, Edgerton L. Preceptor development strategies used in a mixed academic-community teaching hospital. Curr Pharm Teach Learn. 2014; 6(1):167-173. 


\section{American Journal of Pharmaceutical Education 2020; 84 (10) Article 8039.}

14. Skrabal M, Jones R, Nemire R, et al. National survey of volunteer pharmacy preceptors. Am J Pharm Educ. 2008; 72(5):Article 112. 15. Accreditation Council for Pharmacy Education. Accreditation Standards and Guidelines for the Professional Program in Pharmacy Leading to the Doctor of Pharmacy Degree 2016.https://www.acpeaccredit.org/pdf/Standards2016FINAL.pdf. Accessed September 28, 2020.

16. General Pharmaceutical Council of Great Britain Standards. https://www.pharmacyregulation.org/. Accessed September 28, 2020.

17. Australian Health Practitioner Regulation Agency (AHPRA). Pharmacy Board of Australia Intern pharmacist and preceptor guide, Dec 2017. https:/www.pharmacyboard.gov.au/. Accessed September 28, 2020. 18. The Australian Pharmacy Council. Accreditation Standards for Pharmacy Programs in Australia and New Zealand 2020 https:// www.pharmacycouncil.org.au/standards/. Accessed September 28, 2020. 19. Lucas C, Williams K, Tudball J, Walpola R. Community, hospital and industry preceptor perceptions of their role in experiential placements - the need for standardization of preceptor responsibilities and evaluations on students. Curr Pharm Teach Learn. 2018;10(11):1447-1455.

20. The Joanna Briggs Institute. Joanna Briggs Institute Reviewers' Manual 2017: Methodology for JBI Scoping Reviews. Adelaide, Australia: The Joanna Briggs Institute 2017.

21. Arksey H, O’Malley L. Scoping studies: towards a methodological framework. Int J Soc Res Meth. 2005;8(1):19-32. doi: 10.1080/1364557032000119616

22. Levac D, Colquhoun H, O'Brien D. Scoping studies: advancing the methodology. Implement Sci. 2010;5:Article 69.

23. Wells G, Shea B, O'Connell D, et al. The Newcastle-Ottawa Scale (NOS) for assessing the quality of non-randomised studies in meta-analyses. http://www.ohri.ca/programs/clinical_epidemiology/ oxford.asp. Accessed September 28, 2020.

24. Dalton L, Bull R, Taylor S, Galbraith K, Marriott J, Howarth H. Evaluation of the national pharmacy preceptor education program. Aust J Rural Health 2007;15(3):159-165.

25. Davison K, Bullen K, Ling J. Pre-registration pharmacist tutor training: a pilot study. Clin Teach. 2018;15:1-6

26. McDuffie C, Duke L, Stevenson L, et al. Consortium-based approach to an online preceptor development program. Am J Pharm Educ. 2011;75(7):Article 135.

27. Taylor S, Best D, Marriott J, et al. Participant views of an on-line program supporting rural pharmacy preceptors. Focus on Health Professional Education. 2007; 9(3):44-56.

28. Tofade T, Kim J, Lebovitz L, et al. Introduction of a continuing professional development tool for preceptors: Lessons learned. $J$ Pharm Pract. 2015;28(2):212-219.

29. Bolt J, Baranski B, Bell A, Semchuk W. Assessment of preceptor development strategies across Canadian pharmacy residency programs. Can J Hosp Pharm. 2016;69(2):144-148.

30. Hartzler M, Ballantine J, Kauflin M. Results of a survey to assess residency preceptor development methods and precepting challenges. Am J Health Syst Pharm. 2015;72(15):1305-1314.

31. Phillips H, Holler J, Lepkowsky M, May D, May J. Assessment of current practices for developing "preceptors in training". Am J Health Syst Pharm. 2017;74:669-671.

32. Ackman M, Romanick M. Developing preceptors through virtual communities and networks: experiences from a pilot project. Can J Hosp Pharm. 2011;64(6):405-411.
33. Frantzen L, Ordway B. Using lean to develop frontline clinical staff pharmacists as residency program primary preceptors. Hosp Pharm. 2017;52(4):243-245

34. Fuller P, Peters L, Hoel R, Baldwin J, Olsen K. Residency preceptor development and evaluation: a new approach. Am J Health Syst Pharm. 2013;70(18):1605-1608.

35. Loy B, Yang S, Moss J, Kemp D, Brown J. Application of the layered learning practice model in an academic medical center. Hosp Pharm. 2017;52(4):266-272.

36. Watson K, Grover B, Wilson S, DiPaula B, Kendall M, McPherson M. Design and implementation of a strategy for preceptor development in multiple residency programs. Am J Health Syst Pharm. 2014;71(7):526-528.

37. Cerulli J, Briceland L. A streamlined training program for community pharmacy advanced practice preceptors to enable optimal experiential learning opportunities. Am J Pharm Educ. 2004; 68(1-5):H1-H8.

38. Macedo L, Sturpe D, Haines S, Layson-Wolf C, Tofade T, McPherson M. An objective structured teaching exercise (OSTE) for preceptor development. Curr Pharm Teach Learn.

2015;7(5):627-634.

39. Johanson E. (2013). Preceptor Recruitment, Training, and Retention- A Nation-Wide Survey of Colleges of Pharmacy. PhD Thesis Northern Arizona University Publication Number 3606815. 2013;1-183.

40. Ricchetti C, Jun A. Strategies and resources for successful preceptor development. Am J Health Syst Pharm.

2011;68:1837-1842.

41. Vos S, Brown M, Cardello M, et al. The report of the 2017-2018 Professional Affairs Standing Committee: the development of the preceptor self-assessment tool for entrustable professional activities for new graduates. Am J Pharm Educ. 2018; 82(7):885-898. 42. Walter S, Mulherin K, Cox C. A Preceptor competency framework for pharmacists. Part 2 of a 3-part series. Curr Pharm Teach Learn. 2018;10(3):402-410

43. Cox C, Mulherin K, Walter S. National preceptor development program (PDP) prototype. The third of a 3-part series. Curr Pharm Teach Learn 2018;10(3):298-306.

44. Therapeutic Research Center. Pharmacists letter. https:// trchealthcare.com/pharmacists-letter/Accessed September 28, 2020. 45. Assemi M, Corelli R, Ambrose P. Development needs of volunteer pharmacy practice preceptors. Am J Pharm Educ. 2011;75(1):Article 10.

46. Gupte J. The intern debate: who will take responsibility? The Aust J Pharm. 2010;91(1086):4-6.

47. Danielson J, Craddick K, Eccles D, Kwasnik A, O'Sullivan T. A qualitative analysis of common concerns about challenges facing pharmacy experiential education programs. Am J Pharm Educ. 2015;79(1):Article 6.

48. Wilkinson S, Couldry R, Phillips H, Buck B. Preceptor development: providing effective feedback. Hosp Pharm. 2013;48(1):26-32.

49. Payakachat N, Ounpraseuth S, Ragland D, Murawski M. Job and career satisfaction among pharmacy preceptors. Am J Pharm Educ. 2011;75(8):1-153.

50. Praslova L. Adaptation of Kirkpatrick's four level model of training criteria to assessment of learning outcomes and program evaluation in higher education. Educ Asse Eval Acc.

2010;22:215-225 
American Journal of Pharmaceutical Education 2020; 84 (10) Article 8039.

Appendix 1. Description of Included Studies Involving Preceptors of Undergraduate Students with Outcomes Mapped to Domains $(n=13)$

\begin{tabular}{|c|c|c|c|}
\hline $\begin{array}{l}\text { Year, Author, } \\
\text { Country }\end{array}$ & Design & $\begin{array}{c}\text { Participants and } \\
\text { Setting }\end{array}$ & Outcomes Mapped to Domains ${ }^{1}$ \\
\hline $\begin{array}{l}2011 \text { Ackman, } \\
\text { Romanick }^{32} \\
\text { (Canada) }\end{array}$ & $\begin{array}{l}\text { Program description - computer } \\
\text { mediated support network } \\
\text { following a preceptor } \\
\text { development workshop. } \\
\text { Evaluation via electronic } \\
\text { survey of participants and } \\
\text { virtual computer-based } \\
\text { feedback. }\end{array}$ & $\begin{array}{l}\text { Hospital pharmacy } \\
\text { preceptors }(n=26)\end{array}$ & $\begin{array}{l}\text { D1 and D2: Workshop included introduction, } \\
\text { expectations, providing feedback, teaching } \\
\text { pharmaceutical care and rotation design. } \\
\text { Four facilitated computer-mediated } \\
\text { conferencing sessions with preceptors. D3: } \\
\text { Preceptors found support network useful to } \\
\text { share experiences and information with } \\
\text { other preceptors. Challenges included } \\
\text { technology, lack of support and timing of } \\
\text { sessions }\end{array}$ \\
\hline 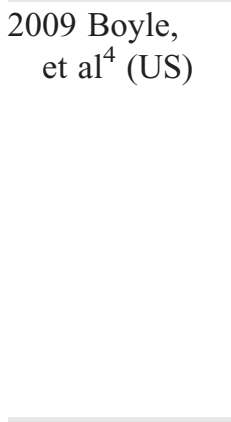 & $\begin{array}{l}\text { Program description - concept, } \\
\text { development and } \\
\text { implementation of an } \\
\text { Academy of Preceptors } \\
\text { (2004) at a US University } \\
\text { and future implications }\end{array}$ & $\begin{array}{l}\text { Pharmacy preceptors of a } \\
\text { USA university - } \\
\text { variable numbers each } \\
\text { year }\end{array}$ & $\begin{array}{l}\text { D1 and D2: Four academy goals were to } \\
\text { recognise preceptor excellence, improve } \\
\text { the management of the experiential } \\
\text { learning courses, develop preceptor } \\
\text { educational skills and facilitate preceptor } \\
\text { networking opportunities. Future focus will } \\
\text { be on the standardization of experiential } \\
\text { programs, training new preceptors and } \\
\text { advanced programs for experienced } \\
\text { preceptors. }\end{array}$ \\
\hline $\begin{array}{l}2004 \text { Cerulli, } \\
\text { Briceland }^{37} \\
\text { (US) }\end{array}$ & $\begin{array}{l}\text { Program description } \\
\text {-implementation and } \\
\text { evaluation of a preceptor } \\
\text { training program to enhance } \\
\text { preceptor skills and patient } \\
\text { care in Community } \\
\text { Pharmacy Advanced } \\
\text { Practice Experiences } \\
\text { (CPAPEs). }\end{array}$ & $\begin{array}{l}\text { Community pharmacy } \\
\text { preceptors }(\mathrm{n}=28) ; \\
\text { Placement students } \\
(\mathrm{n}=30)\end{array}$ & $\begin{array}{l}\text { D1 and D2: Two six-hour face-to-face } \\
\text { preceptor training sessions were developed } \\
\text { which included pre-session assignments, } \\
\text { lectures, discussion groups and role- } \\
\text { playing exercises. D3: Preceptors felt that } \\
\text { content was relevant, interesting, enhanced } \\
\text { their knowledge of pharmaceutical care } \\
\text { and increased confidence in precepting. } \\
\text { Students rated CPAPE learning } \\
\text { experiences positively with } 28 \text { out of } 30 \\
\text { students indicating that they would } \\
\text { recommend this rotation to other students. }\end{array}$ \\
\hline $\begin{array}{l}2007 \text { Dalton, } \\
\text { et } \mathrm{al}^{24} \\
\text { (Australia) }\end{array}$ & $\begin{array}{l}\text { Delivery and evaluation of a } \\
\text { national web-based } \\
\text { preceptor training program } \\
\text { designed specifically for } \\
\text { pharmacy preceptors in rural } \\
\text { areas in } 3 \text { states of Australia. } \\
\text { Evaluation via a print-based } \\
\text { questionnaire. }\end{array}$ & $\begin{array}{l}\text { Pharmacy Preceptor } \\
\text { participants }(n=56) \\
\text { Preceptor evaluations } \\
(n=19)\end{array}$ & $\begin{array}{l}\text { D2: Five modules presented, covering } \\
\text { introduction, focus on the student, focus on } \\
\text { the preceptor, and challenges in precepting } \\
\text { and putting the theory into practice. } \\
\text { Didactic and self-assessment components, } \\
\text { online discussion group and mentoring. } \\
\text { D3: Program strengths were ease of access, } \\
\text { self-directed learning, interactive nature of } \\
\text { program, sharing ideas and feedback. } \\
\text { Limitations included technical delays and } \\
\text { some issues with clarity of program } \\
\text { instructions }\end{array}$ \\
\hline
\end{tabular}


American Journal of Pharmaceutical Education 2020; 84 (10) Article 8039.

(Continued)

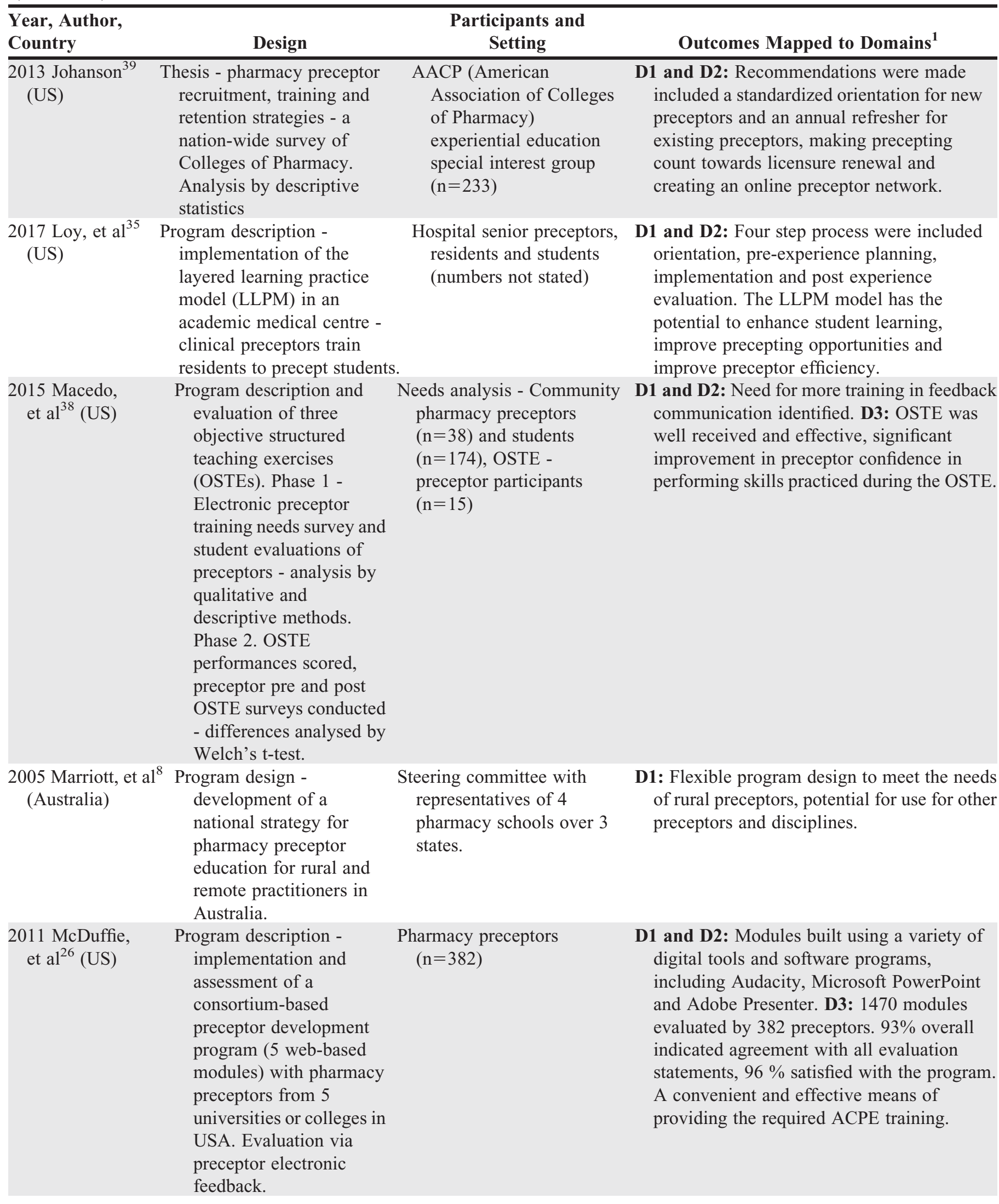


American Journal of Pharmaceutical Education 2020; 84 (10) Article 8039.

(Continued)

\begin{tabular}{|c|c|c|c|}
\hline $\begin{array}{l}\text { Year, Author, } \\
\text { Country }\end{array}$ & Design & $\begin{array}{l}\text { Participants and } \\
\text { Setting }\end{array}$ & Outcomes Mapped to Domains ${ }^{1}$ \\
\hline $\begin{array}{l}007 \text { Taylor, et } \mathrm{al}^{27} \\
\text { (Australia) }\end{array}$ & $\begin{array}{l}\text { Program evaluation - } \\
\text { qualitative evaluation of } \\
\text { a newly developed online } \\
\text { rural pharmacist } \\
\text { preceptor training } \\
\text { program across } 3 \\
\text { Australian states via } \\
\text { structured preceptor } \\
\text { focus groups. }\end{array}$ & Pharmacy preceptors $(n=15)$ & $\begin{array}{l}\text { D3: Participants perceived an improvement in } \\
\text { knowledge, preceptor behaviour and their } \\
\text { attitude to being a preceptor. They reported a } \\
\text { better insight into student learning, gender } \\
\text { and cultural issues, as well as increased } \\
\text { confidence in their role and job satisfaction. }\end{array}$ \\
\hline $\begin{array}{l}2015 \text { Tofade, et } \mathrm{al}^{28} \\
\text { (US) }\end{array}$ & $\begin{array}{l}\text { Program description and } \\
\text { evaluation - project } \\
\text { which encourages } \\
\text { pharmacy preceptors to } \\
\text { take advantage of the } \\
\text { ACPE CPD educational } \\
\text { resources (CPD tool) as a } \\
\text { framework to guide self- } \\
\text { directed reflective } \\
\text { practice - preceptor } \\
\text { evaluation via an online }\end{array}$ & $\begin{array}{r}\text { Pharmacy preceptors }(\mathrm{n}=89) \\
\text { across } 7 \text { pharmacy schools }\end{array}$ & $\begin{array}{l}\text { D1 and D2: Preceptors invited to undergo free } \\
\text { ACPE Preceptor CPD training using pre- } \\
\text { recorded webcasts and to document activities } \\
\text { using the CPD preceptor portfolio. D3: } \\
\text { Online survey six months after training } \\
\text { launch. CPD Portfolio provided motivation } \\
\text { to reflect, plan and set more defined and } \\
\text { realistic goals for students, residents and } \\
\text { themselves. }\end{array}$ \\
\hline
\end{tabular}

\begin{tabular}{|c|c|c|}
\hline $\begin{array}{l}2012 \text { Vos, Trewet } \\
\text { (US) }\end{array}$ & $\begin{array}{l}\text { Program description and } \\
\text { evaluation of a } \\
\text { comprehensive preceptor } \\
\text { development program in } \\
\text { one college of pharmacy. }\end{array}$ & $\begin{array}{l}\text { Pharmacy preceptors (1066 } \\
\text { module evaluations) } \\
\text { Students - (1900 pre, } 3160 \\
\text { post-implementation } \\
\text { preceptor evaluations) }\end{array}$ \\
\hline
\end{tabular}

D1 and D2: Program included live and recorded online programming, preceptor manual, preceptor newsletter, live events and one-on-one practice site visits. D3: Preceptors felt that the activities enhanced their current knowledge, skills, attitudes and values. Students rated preceptors overall higher post-program. preceptor performance (pre and post student evaluations) and the second of teaching strategy (preceptor evaluation).

$\begin{array}{lll}2012 \text { Woloschuk, } & \begin{array}{c}\text { Program description and } \\ \text { Raymond }\end{array} \\ \text { (Canada) } & \begin{array}{l}\text { evaluation of a preceptor } \\ \text { training course for } \\ \text { pharmacists and }\end{array} & \begin{array}{c}\text { Pharmacist preceptors } \\ \text { preceptor evaluations, } 14 \\ \text { pharmacy technicians }\end{array} \\ & \text { within a large regional } \\ & \text { health authority in } \\ & \text { Canada. Qualitative } \\ & \text { course evaluation via } \\ & \text { written surveys and face- } \\ & \text { to-face interviews. }\end{array}$

D1 and D2: Course included self-study readings, interactive seminars, structured practice experience and feedback from a preceptor coach. D3: The most useful parts were receiving feedback from a coach, implementing a lesson plan and identifying and using different learning and teaching styles.

Domain 1 (D1) = Design, Domain 2 (D2) = Delivery, Domain $3(\mathrm{D} 3)=$ Evaluation 
American Journal of Pharmaceutical Education 2020; 84 (10) Article 8039.

Appendix 2. Description of Included Studies Involving Preceptors of Postgraduate Students with Outcomes Mapped to Domains ( $\mathrm{n}=\mathbf{8})$

\begin{tabular}{|c|c|c|c|}
\hline $\begin{array}{l}\text { Year, Author, } \\
\text { Country }\end{array}$ & Design & $\begin{array}{c}\text { Participants and } \\
\text { Setting }\end{array}$ & Outcomes Mapped to Domains ${ }^{2}$ \\
\hline $\begin{array}{l}2016 \text { Bolt, et } \mathrm{al}^{29} \\
\text { (Canada) }\end{array}$ & $\begin{array}{l}\text { Prospective online survey of } \\
\text { current practices in preceptor } \\
\text { development, certification and } \\
\text { competencies in hospital } \\
\text { pharmacy residency programs } \\
\text { across Canada. }\end{array}$ & $\begin{array}{l}\text { Hospital pharmacy } \\
\text { residency } \\
\text { co-ordinators }(n=14)\end{array}$ & $\begin{array}{l}\text { D1 and D2: Programs were diverse } \\
\text { and provided education or } \\
\text { orientation to preceptors, mainly } \\
\text { as live events or modules. There } \\
\text { was a lack of standardized } \\
\text { preceptor competencies and/or } \\
\text { certification. All programs } \\
\text { assessed preceptor performance } \\
\text { via formal evaluation by } \\
\text { residents. }\end{array}$ \\
\hline 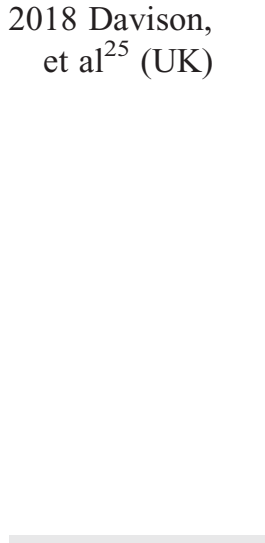 & $\begin{array}{l}\text { Program description - pilot to } \\
\text { identify needs and deliver } \\
\text { training to pre-registration } \\
\text { supervisors in North-East } \\
\text { England. Pre- and post-training } \\
\text { evaluation via preceptor } \\
\text { electronic questionnaire and } \\
\text { semi-structured interviews. }\end{array}$ & $\begin{array}{l}\text { Pharmacy preceptors } \\
\quad \text { (Survey } n=24 \\
\text { Interviews } n=3 \text { ) }\end{array}$ & $\begin{array}{l}\text { D1 and D2: Three training sessions } \\
\text { over a two-month period - } \\
\text { content included introduction, } \\
\text { principles of work-based } \\
\text { learning and teaching, } \\
\text { assessment and feedback, } \\
\text { managing difficult trainees and } \\
\text { quality control. D3: Positive } \\
\text { shift in all domains covered by } \\
\text { the program, except reflective } \\
\text { practice. Potential to improve } \\
\text { the standardization of preceptor } \\
\text { training in UK. }\end{array}$ \\
\hline $\begin{array}{l}2014 \text { Elmore, } \\
\text { et } \mathrm{al}^{13} \text { (US) }\end{array}$ & $\begin{array}{l}\text { Program description - } \\
\text { design and implementation } \\
\text { of a residency preceptor } \\
\text { development program } \\
\text { in an academic-community } \\
\text { teaching hospital. }\end{array}$ & $\begin{array}{l}\text { Hospital pharmacy } \\
\text { preceptors } \\
\text { (experienced or } \\
\text { in training) }(\mathrm{n}=26)\end{array}$ & $\begin{array}{l}\text { D1 and D2: Two program streams, } \\
\text { one for experienced preceptors } \\
\text { and one for preceptors-in- } \\
\text { training. Preceptors meet } \\
\text { regularly and share experiences, } \\
\text { preceptors-in-training assigned } \\
\text { mentors. Evaluation via annual } \\
\text { preceptor self-assessment } \\
\text { worksheets, formative preceptor } \\
\text { peer evaluation and resident } \\
\text { evaluation of preceptors. }\end{array}$ \\
\hline $\begin{array}{l}2017 \text { Frantzen, } \\
\text { Ordway }{ }^{33} \\
\text { (US) }\end{array}$ & $\begin{array}{l}\text { Program description - The Lean } \\
\text { concept to develop frontline } \\
\text { clinical staff pharmacists at a } \\
\text { four-hospital community health } \\
\text { care system as residency } \\
\text { program primary preceptors. }\end{array}$ & $\begin{array}{l}\text { Hospital clinical } \\
\text { pharmacists }(n=20)\end{array}$ & $\begin{array}{l}\text { D1 and D2: Precepting skills } \\
\text { developed using multiple } \\
\text { training modalities over } 2 \text { years. } \\
\text { Program allowed those } \\
\text { providing direct patient care } \\
\text { services to be the drivers of } \\
\text { learning }\end{array}$ \\
\hline
\end{tabular}


American Journal of Pharmaceutical Education 2020; 84 (10) Article 8039.

(Continued)

\begin{tabular}{|c|c|c|c|}
\hline $\begin{array}{l}\text { Year, Author, } \\
\text { Country }\end{array}$ & Design & $\begin{array}{l}\text { Participants and } \\
\text { Setting }\end{array}$ & Outcomes Mapped to Domains ${ }^{2}$ \\
\hline $\begin{array}{l}2013 \text { Fuller, } \\
\text { et } \mathrm{al}^{34} \text { (US) }\end{array}$ & $\begin{array}{l}\text { Program description - design and } \\
\text { implementation of a hospital } \\
\text { pharmacy residency preceptor } \\
\text { development program in a large } \\
\text { medical center hospital. }\end{array}$ & $\begin{array}{l}\text { Hospital pharmacy resident } \\
\text { preceptors }(n=45)\end{array}$ & $\begin{array}{l}\text { D1 and D2: Preceptors must } \\
\text { submit a letter of interest in } \\
\text { becoming a preceptor, must } \\
\text { complete a preceptor orientation } \\
\text { session and must obtain } 10 \\
\text { preceptor education credit points } \\
\text { every } 10 \text { years. }\end{array}$ \\
\hline 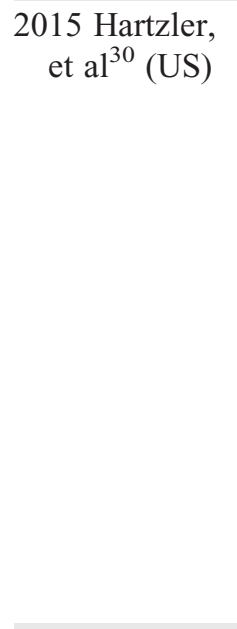 & $\begin{array}{l}\text { Online survey review of hospital } \\
\text { pharmacy residency co- } \\
\text { ordinators/preceptors and } \\
\text { residents to investigate the } \\
\text { current preceptor development } \\
\text { programs in place, the } \\
\text { challenges involved and future } \\
\text { opportunities. }\end{array}$ & $\begin{array}{l}\text { Hospital pharmacy } \\
\text { residency co-ordinators/ } \\
\text { preceptors and } \\
\text { residents }(n=1437)\end{array}$ & $\begin{array}{l}\text { D1 and D2: Primary methods of } \\
\text { preceptor development were } \\
\text { self-study and continuing } \\
\text { education sessions. Less than } \\
\text { half of the institutions had a } \\
\text { policy for specific preceptor } \\
\text { development. Main barrier to } \\
\text { preceptor development was lack } \\
\text { of time. Main preceptor } \\
\text { challenge was providing } \\
\text { effective verbal and written } \\
\text { feedback. Residents identified } \\
\text { good communication as the most } \\
\text { important characteristic of a } \\
\text { good preceptor. }\end{array}$ \\
\hline 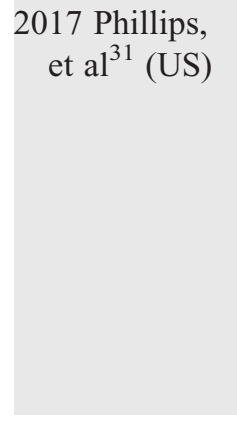 & $\begin{array}{l}\text { Survey of resident program } \\
\text { directors (RPDs) to assess their } \\
\text { current practices in preceptor-in- } \\
\text { training (PIT) programs. } \\
\text { Participants contacted by } \\
\text { telephone or email to complete a } \\
\text { non-validated electronic survey. }\end{array}$ & $\begin{array}{l}\text { Resident program } \\
\text { directors of academic } \\
\text { medical centres }(n=71)\end{array}$ & $\begin{array}{l}\text { D1 and D2: Only } 23 \% \text { of } \\
\text { respondents had an established } \\
\text { PIT program. Skills } \\
\text { development included } \\
\text { orientation, foundational } \\
\text { workshops and ongoing } \\
\text { development. Programs } \\
\text { encouraged regular attendance } \\
\text { at topic discussions and } \\
\text { involvement in student rotations. }\end{array}$ \\
\hline 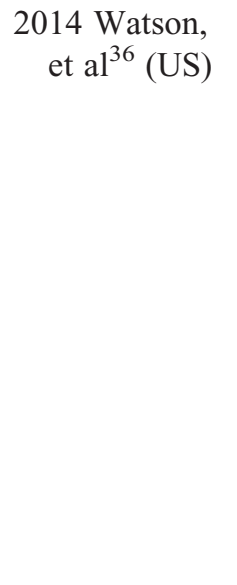 & $\begin{array}{l}\text { Program description -strategy to } \\
\text { create a hospital pharmacy } \\
\text { preceptor development program } \\
\text { for multiple residency programs. }\end{array}$ & $\begin{array}{l}\text { Preceptors from } 13 \text { hospital } \\
\text { residency and } 2 \text { fellowship } \\
\text { programs (numbers not stated) }\end{array}$ & $\begin{array}{l}\text { D1 and D2: Program designed to } \\
\text { provide a standardized yet } \\
\text { multifaceted approach to } \\
\text { providing activities that meet the } \\
\text { needs of all preceptors } \\
\text { regardless of their program or } \\
\text { specialty. Potential benefits were } \\
\text { improved quality of preceptor } \\
\text { development and time } \\
\text { efficiency. However, it does not } \\
\text { take the place of specific } \\
\text { residency programs and } \\
\text { individualised preceptor } \\
\text { development. }\end{array}$ \\
\hline
\end{tabular}

Domain $1(\mathrm{D} 1)=$ Design, Domain $2(\mathrm{D} 2)=$ Delivery, Domain $3(\mathrm{D} 3)=$ Evaluation 